\title{
Polyphasic Characterization of Pigmented Strains of Xanthomonas Pathogenic to Cashew Trees
}

\begin{abstract}
Marco A. S. Gama and Rosa L. R. Mariano, Phytobacteriology Laboratory, Department of Agronomy, Universidade Federal Rural de Pernambuco, Av. Dom Manoel de Medeiros, s/n, Dois Irmãos, CEP 52171-900, Recife-PE, Brasil; Francisco M. P. Viana, Laboratory of Plant Pathology, National Center for Tropical Agroindustrial Research, Empresa Brasileira de Pesquisa Agropecuária, Rua Dra. Sara Mesquita, 2270, Planalto PICI, CEP 60511-110, Fortaleza-CE, Brasil; Marisa A. S. V. Ferreira, Institute of Biological Sciences, Department of Plant Pathology, Universidade de Brasília, Campus Universitário - Asa Norte, CEP 70910-900, Brasília-DF, Brasil; and Elineide B. Souza, Department of Microbiology, Universidade Federal Rural de Pernambuco, Av. Dom Manoel de Medeiros, s/n, Dois Irmãos, CEP 52171-900, Recife-PE, Brasil
\end{abstract}

\begin{abstract}
Gama, M. A. S., Mariano, R. L. R., Viana, F. M. P., Ferreira, M. A. S. V., and Souza, E. B. 2011. Polyphasic characterization of pigmented strains of Xanthomonas pathogenic to cashew trees. Plant Dis. 95:793-802.

The export of cashew (Anacardium occidentale) nuts generates millions of dollars for the Brazilian economy annually. However, production may be limited by the occurrence of diseases that affect cashew trees, such as Xanthomonas spot and angular leaf spot, which are caused by pigmented strains of Xanthomonas and Xanthomonas citri pv. anacardii, respectively. Thirty-one pigmented strains of Xanthomonas were characterized for phenotypic, pathogenic, and molecular attributes. These strains were similar to $X$. citri pv. anacardii in phenotypical characteristics, sensitivity to antibiotics and copper compounds used in agriculture, epidemiology, and repetitive sequence-based

polymerase chain reaction (rep-PCR) profiles. When inoculated into Brazilian pepper, cashew, mango, and hog plum seedlings, the pigmented strains of Xanthomonas and X. citri pv. anacardii produced similar symptoms. However, the pigmented strains of Xanthomonas were more aggressive toward cashew plants than toward the other hosts tested, which confirms their specificity. We conclude that pigmented strains of Xanthomonas are very aggressive on cashew trees and should not be considered casual pathogens of these hosts. Moreover, based on our results from rep-PCR and IS1595-PCR amplification, we suggest that these strains constitute a variant of $X$. citri pv. anacardii.
\end{abstract}

The production of cashew nuts (Anacardium occidentale L.) in Brazil is traditionally intended for the international market (14). In 2007, exports of cashews ready for consumption reached 51 thousand tons, generating approximately 225 million U.S. dollars for the Brazilian economy (6). This production may be compromised by the many diseases affecting cashew trees, including Xanthomonas spot caused by Xanthomonas campestris pv. mangiferaeindicae (Patel et al.) Robbs et al. (pigmented strains of Xanthomonas) (2932) and angular leaf spot caused by Xanthomonas citri pv. anacardii (Patel et al.) Ah-You et al. $(1,2)$.

$X$. campestris pv. mangiferaeindicae was originally reported causing mango (Mangifera indica L.) bacterial black spot in South Africa by Doidge (5), and was named Bacillus mangifera Doidge. In 1948, similar symptoms were observed in mango leaves and fruit in India by Patel et al. (16,17), who proposed the creation of a new species, Pseudomonas mangiferae-indicae Patel et al., because of differences observed between these strains and those from South Africa. Additionally, the authors described the pathogenicity of this bacterium in cashew trees without any further reports on its occurrence in nature or studies on its pathosystem. In 1974, this species was renamed Xanthomonas campestris pv. mangiferaeindicae by Robbs et al. (23). Interestingly, while both pigmented and nonpigmented strains of this bacterium have been isolated from mango trees with symptoms of bacterial black spot

Corresponding author: R. L. R. Mariano, E-mail: rrmbac@gmail.com

Accepted for publication 5 March 2011.

doi:10.1094/PDIS-05-10-0321

(C) 2011 The American Phytopathological Society
$(19,22)$, the pigmented strains are regarded as casual pathogens of this host (1).

In 1981, Robbs et al. (22) reported the first occurrence of angular leaf spot in cashew trees in the northeast and southeast regions of Brazil. Subsequently, in 1999, Papa et al. (15) observed the presence of the disease in Mato Grosso do Sul. From 2003, in addition to the usual angular leaf spots, atypical spots have been observed in cashew leaves and fruits in the Brazilian states of Piauí, Ceará (29-32), Minas Gerais (29,30,32), and São Paulo (8). Viana et al. (29) named this disease Xanthomonas spot. In contrast to the nonpigmented strains obtained from cashew with angular leaf spot $(15,22)$, only pigmented strains of Xanthomonas have been isolated from lesions of Xanthomonas spot (8).

The most typical symptoms of Xanthomonas spot can be seen in the veins and surrounding tissues, which become dark, although the leaf blade may occasionally present angular spots. The darkening moves from the main vein to the secondary veins (32) and to the petioles, and may cause extensive dry necrosis of twigs and their tips (8). On the fruit, dark necrotic lesions are usually observed; however, the lesion may be just a big oily spot whose center will later become necrotic (32). To date, no symptoms have been observed on the pseudofruit.

The study of the pathogenic variability of a worldwide collection of strains of $X$. campestris pv. mangiferaeindicae from several genera of Anacardiaceae allowed Ah-You et al. (1) to define three groups pathogenic on different hosts. These groups are genetically distinct, based on the evolutionary divergence of the genomes derived from amplified fragment length polymorphism (AFLP) analysis, and related to X. axonopodis groups 9.5, 9.6, and 9.7, which were previously determined by restriction fragment length polymorphism (RFLP) (21). Thus, it was proposed that $X$. campestris pv. mangiferaeindicae be separated into three pathovars of $X$. 
axonopodis Starr \& Garces; namely, X. axonopodis pv. mangiferaeindicae (Starr \& Garces) Ah-You et al., X. axonopodis pv. anacardii (Starr \& Garces) Ah-You et al., and X. axonopodis pv. spondiae (Starr \& Garces) Ah-You et al. (1). Of the three pathovars in this new classification, only pv. mangiferaeindicae strains contain a large number of insertion elements of the IS1595 family in their genome, which has become an important tool for differentiating this pathovar (1).

Using multilocus sequence analysis (MLSA), AFLP, and DNADNA hybridization, Ah-You et al. (2) found congruent phylogenetic relationships of pv. mangiferaeindicae with strains of $X$. axonopodis subgroup 9.5, which includes $X$. axonopodis pv. citri Vauterin et al. Similarly, pv. anacardii, which is responsible for the angular leaf spot in cashew trees in Brazil, was included in $X$. axonopodis subgroup 9.6 ( $X$. fuscans Schaad et al. synonymy). Based on data from the thermal stability of DNA reassociation, which were consistent with the AFLP and MLSA results, the authors found that pvs. mangiferaeindicae and anacardii have a consistent level of similarity and thus belong to the same species. Together, these data support the recent proposal to raise $X$. axonopodis pv. citri to the species level as X. citri (Hasse) Gabriel et al. (25), and therefore to reclassify the pvs. mangiferaeindicae and anacardii as $X$. citri pathovars, namely $X$. citri pv. mangiferaeindicae (mango bacterial black spot) and $X$. citri pv. anacardii (cashew angular leaf spot).

Brazilian pigmented strains of Xanthomonas from cashew trees with symptoms of Xanthomonas spot were not included in the reclassification studies conducted by Ah-You et al. and published in 2007 and 2009 (1,2). Moreover, monitoring cashew orchards in Piauí and Ceará has shown that these pigmented strains can cause large losses since the infected fruits are not suitable for marketing (32). Therefore, the objective of this study was to characterize the pigmented strains of Xanthomonas obtained from affected cashew trees with regard to their phenotypic, molecular, and pathogenic profiles trying to elucidate the etiology of Xanthomonas spot in cashew trees.

\section{Materials and Methods}

Bacterial suspensions for all experiments were prepared in sterile distilled water (SDW) from strains cultured on nutrient-yeast extract-dextrose-agar (NYDA) medium (20 g/liter agar, $10 \mathrm{~g} / \mathrm{liter}$ dextrose, $5 \mathrm{~g} /$ liter peptone, $5 \mathrm{~g} /$ liter yeast extract, and $3 \mathrm{~g} /$ liter meat extract in $\mathrm{dd}_{2} \mathrm{O}$ ) at $29^{\circ} \mathrm{C}$ for $36 \mathrm{~h}$, unless otherwise noted. Bacterial concentrations were determined based on absorbance and adjusted to an $A_{570}=0.06\left(10^{8} \mathrm{CFU} / \mathrm{ml}\right)$ using a spectrophotometer. All of the experiments and tests described were performed in duplicate.

Pathogen isolation from cashew trees with typical Xanthomonas spot symptoms. Leaves and fruit from cashew trees presenting typical symptoms of Xanthomonas spot were collected from orchards in the states of Ceará, Piauí, and São Paulo. We performed pathogen isolations on NYDA media and pathogenicity tests on cashew tree (clone CCP 76) seedlings approximately 100 days old according to protocols previously established by Mariano and Silveira (12).

Bacterial suspensions were inoculated into plants by injection (12) on the intermediary portion of the midrib of the first four leaves counting from the apex of each plant. The tests were conducted with four replicates per isolate. Each replicate consisted of one inoculated leaf, with the selection of seedlings, leaf, and inoculated isolate performed randomly. The pathogen was reisolated from lesions characteristic of Xanthomonas spot 30 days after inoculation, thus completing Koch's Postulates. The strains were subsequently preserved in SDW and by lyophilization. Pigmented isolate IBSBF873, isolated from mango bacterial black spot, identified as $X$. campestris pv. mangiferaeindicae, and not reclassified by Ah-You et al. (1,2), and the strains IBSBF1971 and IBSBF1508, which cause angular leaf spots in cashew trees and which were reclassified by these authors as $X$. citri pv. anacardii (Table 1), were included in the pathogenicity tests to compare the symptoms of the angular leaf spot with those of Xanthomonas spot.

Phenotypic characterization. The phenotypic characterization of the 31 pigmented strains of Xanthomonas (Table 1), which were causal agents of Xanthomonas spot, was conducted as previously described by Schaad et al. (24). Two X. citri pv. anacardii strains (IBSBF1508 and IBSBF1971), causal agents of angular leaf spot in cashew, one pigmented (IBSBF873) and two nonpigmented strains (IBSBF657 and IBSBF1230) isolated from mango bacterial black spots and identified as $X$. campestris pv. mangiferaeindicae $(1,2)$ (Table 1) were included in order to compare the phenotypic profiles. Additionally, the growth of three pigmented strains of Xanthomonas (TAQ18, TAQ13, and CCP76) was analyzed at different temperatures, $\mathrm{pH}$ levels, and salt concentrations as described by Nascimento et al. (13). The tests were performed in triplicate for each isolate in which each replicate consisted of one tube or plate, depending on the test performed.

In vitro sensitivity to the antibiotics and copper compounds used in agriculture. Commercial products based on copper oxychloride (1,500 mg/liter) (Fungitol Azul; Du Pont do Brasil S.A., Brazil), copper hydroxide (1,614 mg/liter) (Kocide WDG Bioactive; Du Pont do Brasil S.A.), oxytetracycline (600 mg/liter) (Mycoshield; Laboratórios Pfizer LTDA, Brazil), kasugamycin (60 mg/liter) (Hokko Kasumin; Arysta Lifescience do Brasil Indústria Química e Agropecuária, Brazil), oxytetracycline (90 mg/liter) + tribasic copper sulfate $(1,500 \mathrm{mg} / \mathrm{liter})$ (Agrimaicin 500; Laboratórios Pfizer LTDA), and oxytetracycline (76.6 mg/liter) + streptomycin sulfate (367.2 mg/liter) (Agri-Micina PM; Laboratórios Pfizer LTDA) were diluted into $4.5 \mathrm{ml}$ of SDW, vortexed for $3 \mathrm{~min}$, and added to sterile NYDA medium. Aliquots of $5 \mu \mathrm{l}\left(5 \times 10^{5}\right.$ $\mathrm{CFU}$ ) of a bacterial suspension were spotted onto petri dishes containing NYDA supplemented with the compounds at the appropriate concentration. The dishes were incubated at $29^{\circ} \mathrm{C}$ for $72 \mathrm{~h}$. All of the pigmented strains of Xanthomonas were evaluated as well as two X. citri pv. anacardii strains (IBSBF1508 and IBSBF1971), one pigmented (IBSBF873) and two nonpigmented strains (IBSBF657 and IBSBF1230) identified as X. campestris pv. mangiferaeindicae for comparison (Table 1). The proper positive control was included in all tests conducted with antibiotics or copper fungicides. The tests were conducted with four replicates per isolate in which each replicate consisted of one inoculation point on a different plate. Those strains that failed to grow at confluent levels were considered to be sensitive.

Molecular characterization. Extraction and quantification of genomic DNA. Genomic DNA extractions were performed as described by Ausubel et al. (3) for all strains listed on Table 1. Genomic DNA was quantified by comparing the High DNA Mass Ladder (Invitrogen, Brazil) with a mixture containing $3 \mu$ of concentrated DNA and $2 \mu \mathrm{l}$ of $6 \times$ loading buffer containing DNA Loading Dye (Fermentas Life Sciences, Canada). Samples were submitted to electrophoresis on a $1 \%$ agarose gel in $0.5 \times \mathrm{TBE}$ buffer ( $45 \mathrm{mM}$ Tris, $45 \mathrm{mM}$ boric acid, and $1 \mathrm{mM}$ EDTA) at $90 \mathrm{~V}$ for $40 \mathrm{~min}$. The gel was stained for $15 \mathrm{~min}$ with $0.5 \mu \mathrm{g} / \mathrm{ml}$ ethidium bromide and then immersed in distilled water for $15 \mathrm{~min}$ to remove excess ethidium bromide. The gel was then photographed, and after quantification, the DNA samples were diluted to a final concentration of $10 \mathrm{ng} / \mu \mathrm{l}$ and stored at $-20^{\circ} \mathrm{C}$.

Repetitive sequence-based polymerase chain reaction (rep-PCR) analysis. The REP, ERIC, and BOX reactions were performed as described by Louws et al. (10) and consisted of buffer $(50 \mathrm{mM}$ $\mathrm{KCl}, 10 \mathrm{mM}$ Tris $\mathrm{HCl}), 1.5 \mathrm{mM} \mathrm{MgCl} 2,100 \mu \mathrm{M}$ dNTPs, $2 \mu \mathrm{M}$ primer, $1 \mathrm{U}$ Taq DNA Polymerase (Fermentas Life Sciences), and $50 \mathrm{ng}$ DNA. Samples were amplified in a PTC-100 model thermocycler (MJ Research, USA). Negative controls consisting of reactions without template DNA were included in all experiments to check for contaminant DNA. Products were separated by electrophoresis on a $1.5 \%$ agarose gel at $90 \mathrm{~V}$ for $2.5 \mathrm{~h}$ in $0.5 \times$ TBE buffer. GenRuler 100 bp DNA Ladder (Fermentas Life Sciences) was used to determine the product sizes. Gels were stained and photographed as previously described in this section. 
IS1595 sequence amplification. The 1,812-bp sequence of the insertion element IS1595 from X. citri pv. mangiferaeindicae (GenBank AF249895) was used to design primers using the Primer Blast tool (http://www.ncbi.nlm.nih.gov/tools/primer-blast). We selected three primer pairs: (i) IS 1F - CATGGCCGAGCGTGA AGCCA and IS 1R - CGCGCATGGCGTAAGCGAAC (expected product size $=666 \mathrm{bp}$ ), (ii) IS $2 \mathrm{~F}$ - CGGTTGGCCACCGAG CAGAG and IS 2R - AAGCTGCGCACCGGCTCAAT (expected product size $=829 \mathrm{bp}$ ), and (iii) IS 3F - GGGCGACCTGCGTTA AGCGT and IS 3R - AAGCTGCGCACCGGCTCAAT (expected product size $=967 \mathrm{bp}$ ). The primers were synthesized (Integrated DNA Technologies, Brazil), and the PCR reactions consisted of $1 \times$ buffer $(50 \mathrm{mM} \mathrm{KCl}, 10 \mathrm{mM}$ Tris $\mathrm{HCl}), 1.5 \mathrm{mM} \mathrm{MgCl}_{2}, 50 \mu \mathrm{M}$ dNTPs, $1 \mu \mathrm{M}$ primer, $1 \mathrm{U}$ of Taq polymerase, and $30 \mathrm{ng}$ of DNA. The PCR conditions were as follows: $95^{\circ} \mathrm{C}$ for $2 \mathrm{~min}$, followed by 30 cycles of $1 \mathrm{~min}$ at $95^{\circ} \mathrm{C}, 1 \mathrm{~min}$ at $63^{\circ} \mathrm{C}$, and $1 \mathrm{~min}$ at $72^{\circ} \mathrm{C}$, and a final extension step of $72^{\circ} \mathrm{C}$ for $10 \mathrm{~min}$. The reactions were performed in a PTC-100 model thermocycler (MJ Research). Following amplification, the products were submitted to electrophoresis in $1 \%$ agarose gels, stained, and photographed as previously described.

Methods of cashew leaf inoculation. Isolate TAQ18 (a pigmented strain of Xanthomonas) was inoculated into the four first leaves from the apex of a cashew seedlings (clone CCP 76) that was previously grown in a greenhouse. Inoculation was performed using the following methods: (i) spraying with injury, (ii) spraying without injury, (iii) deposition with injury on the midrib, (iv) injection into the intermediate portion of the midrib, and (v) infiltration on the leaf blade.

For the spraying method, leaves with or without injury were sprayed with the bacterial suspensions until we could observe bacterial suspension runoff. The wounds were inflicted at four points along the leaf blade with the aid of a cushion containing six pins. For the deposition method with injury, $10 \mu \mathrm{l}$ of the bacterial suspension was deposited onto the wounds made in the intermediate portion of the midrib of the leaf. For the injection method, 100 $\mu l$ of the bacterial suspension was infiltrated in the intermediate portion of the midrib of the leaf with the aid of a hypodermic sy-

Table 1. Description of the Xanthomonas strains related to the Anacardiaceae host family used in this study

\begin{tabular}{|c|c|c|c|c|c|}
\hline Strains $^{\mathrm{u}}$ & Origin/Year of isolation & Host & Disease & Presence of pigment & Identification \\
\hline CAST2 & Brazil (PI) 2008 & Anacardium occidentale & $\mathrm{XS}^{\mathrm{v}}$ & Pigmented & Xanthomonas ${ }^{\mathrm{w}}$ \\
\hline CCP76 & Brazil (CE) 2006 & A. occidentale & $\mathrm{XS}$ & Pigmented & Xanthomonas \\
\hline TAQ1 & Brazil (SP) 2009 & A. occidentale & XS & Pigmented & Xanthomonas \\
\hline TAQ2 & Brazil (SP) 2009 & A. occidentale & XS & Pigmented & Xanthomonas \\
\hline TAQ3 & Brazil (SP) 2009 & A. occidentale & XS & Pigmented & Xanthomonas \\
\hline TAQ4 & Brazil (SP) 2009 & A. occidentale & XS & Pigmented & Xanthomonas \\
\hline TAQ5 & Brazil (SP) 2009 & A. occidentale & XS & Pigmented & Xanthomonas \\
\hline TAQ6 & Brazil (SP) 2009 & A. occidentale & XS & Pigmented & Xanthomonas \\
\hline TAQ7 & Brazil (SP) 2009 & A. occidentale & XS & Pigmented & Xanthomonas \\
\hline TAQ9 & Brazil (SP) 2009 & A. occidentale & XS & Pigmented & Xanthomonas \\
\hline TAQ10 & Brazil (SP) 2009 & A. occidentale & XS & Pigmented & Xanthomonas \\
\hline TAQ11 & Brazil (SP) 2009 & A. occidentale & XS & Pigmented & Xanthomonas \\
\hline TAQ12 & Brazil (SP) 2009 & A. occidentale & XS & Pigmented & Xanthomonas \\
\hline TAQ13 & Brazil (SP) 2009 & A. occidentale & XS & Pigmented & Xanthomonas \\
\hline TAQ14 & Brazil (SP) 2009 & A. occidentale & XS & Pigmented & Xanthomonas \\
\hline TAQ15 & Brazil (SP) 2009 & A. occidentale & XS & Pigmented & Xanthomonas \\
\hline TAQ16 & Brazil (SP) 2009 & A. occidentale & XS & Pigmented & Xanthomonas \\
\hline TAQ17 & Brazil (SP) 2009 & A. occidentale & XS & Pigmented & Xanthomonas \\
\hline TAQ18 & Brazil (SP) 2009 & A. occidentale & XS & Pigmented & Xanthomonas \\
\hline TAQ19 & Brazil (SP) 2009 & A. occidentale & XS & Pigmented & Xanthomonas \\
\hline TAQ20 & Brazil (SP) 2009 & A. occidentale & XS & Pigmented & Xanthomonas \\
\hline TAQ22 & Brazil (SP) 2009 & A. occidentale & XS & Pigmented & Xanthomonas \\
\hline TAQ23 & Brazil (SP) 2009 & A. occidentale & XS & Pigmented & Xanthomonas \\
\hline TAQ24 & Brazil (SP) 2009 & A. occidentale & XS & Pigmented & Xanthomonas \\
\hline TAQ29 & Brazil (SP) 2009 & A. occidentale & XS & Pigmented & Xanthomonas \\
\hline TAQ30 & Brazil (SP) 2009 & A. occidentale & XS & Pigmented & Xanthomonas \\
\hline TAQ31 & Brazil (SP) 2009 & A. occidentale & XS & Pigmented & Xanthomonas \\
\hline TAQ32 & Brazil (SP) 2009 & A. occidentale & XS & Pigmented & Xanthomonas \\
\hline TAQ34 & Brazil (SP) 2009 & A. occidentale & XS & Pigmented & Xanthomonas \\
\hline XCMF1 & Brazil (PI) 2008 & A. occidentale & XS & Pigmented & Xanthomonas \\
\hline $\mathrm{XCMF} 2$ & Brazil (PI) 2008 & A. occidentale & XS & Pigmented & Xanthomonas \\
\hline SAPA & Brazil (SP) 2009 & A. occidentale & - & Pigmented & Saprophytic ${ }^{\mathrm{x}}$ \\
\hline SAPC & Brazil (SP) 2009 & A. occidentale & - & Nonpigmented & Saprophytic \\
\hline IBSBF2579 & Brazil & A. occidentale & AS & Nonpigmented & $X$. citri pv. anacardii ${ }^{\mathrm{y}}$ \\
\hline IBSBF1508 & Brazil & A. occidentale & AS & Nonpigmented & $X$. citri pv. anacardii \\
\hline IBSBF1971 & Brazil & A. occidentale & AS & Nonpigmented & $X$. citri pv. anacardii \\
\hline IBSBF2585 & India & Spondias dulcis & AS & Nonpigmented & $X$. axonopodis pv. spondiae ${ }^{\mathrm{y}}$ \\
\hline IBSBF2586 & India & Mangifera indicae & AS & Nonpigmented & $X$. citri $^{\mathrm{pv} .}$ mangiferaeindicae $\mathrm{y}$ \\
\hline IBSBF657 & Brazil 1988 & M. indicae & AS & Nonpigmented & $X$. campestris pv. mangiferaeindicae ${ }^{\mathrm{Z}}$ \\
\hline IBSBF1230 & Brazil & M. indicae & AS & Nonpigmented & $X$. campestris pv. mangiferaeindicae \\
\hline IBSBF873 & Brazil 1974 & M. indicae & AS & Pigmented & $X$. campestris pv. mangiferaeindicae \\
\hline
\end{tabular}

" IBSBF873 = NCPPB 3110; IBSBF2579 = ICMP4088; IBSBF2585 = LMG17211; IBSBF2586 = ICMP5740, LMG941, NCPPB490, and ATCC11637. IBSBF: Phytobacteria Culture Collection of Instituto Biológico, São Paulo, Brazil; ICMP: International Collection of Microorganisms from Plants, Auckland, New Zealand; LMG: Belgian Coordinated Collections of Micro-organisms (University of Ghent, Belgium); NCPPB: National Collection of Plant Pathogenic Bacteria (CSL, York, United Kingdom); ATCC: American Type Culture Collection, Rockville, MD, USA. All strains are available at the Phytopathogenic Bacteria Collection housed at the Phytobacteriology Laboratory at the Universidade Federal Rural de Pernambuco (Pernambuco, Brazil).

$\checkmark$ XS = Xanthomonas spot, AS = angular spot.

w Pigmented strains of Xanthomonas obtained from cashew trees with symptoms of the Xanthomonas spot.

x Saprophytic strains from cashew leaves.

y Strains of $X$. citri pv. anacardii, X. axonopodis pv. spondiae, and X. citri pv. mangiferaeindicae reclassified by Ah-You et al. (1,2).

${ }^{\mathrm{z}}$ Nonpigmented and pigmented strains of $X$. campestris pv. mangiferaeindicae obtained from bacterial black spot from mango trees and not reclassified by Ah-You et al. $(1,2)$. 
ringe. For the infiltration method, $100 \mu \mathrm{l}$ of the bacterial suspension was infiltrated into the four points of the abaxial surface of the leaves with the aid of a hypodermic syringe without needle. The tests were conducted with four replicates per inoculation method in which each replicate consisted of one inoculated leaf, with the selection of seedlings, leaf, and inoculated isolate performed randomly. The seedlings were incubated in a greenhouse, and those that were sprayed with or without injury underwent a pre- and posttreatment in a moist chamber for $24 \mathrm{~h}$. The plants were evaluated daily for 25 days to determine the incubation period of the disease, which is the number of days from inoculation to the onset of first symptoms. Twenty-five days after inoculation, we evaluated the incidence of disease, which is defined here as the percentage of leaves or inoculation points with disease symptoms, and the disease severity, which was estimated using the Assess 2.0: Image Analysis Software for Plant Disease Quantification (APS Press, USA).

Epidemiological components of Xanthomonas spot in cashew seedlings. We used 31 pigmented strains of Xanthomonas as well as two X. citri pv. anacardii strains (IBSBF1508 and IBSBF1971), one pigmented (IBSBF873) and two nonpigmented strains (IBSBF657 and IBSBF1230) identified as X. campestris pv. mangiferaeindicae (Table 1). The strains were inoculated on the first four leaves from the apex of cashew seedlings (clone CCP76) using the infiltration method at six points along the surface of the leaf. The negative control was treated with SDW. The tests were conducted with four replicates per isolate in which each replicate consisted of one inoculated leaf, with the selection of seedlings, leaf, and inoculated isolate performed randomly. The plants were incubated in the greenhouse and observed for 25 days to determine the incubation period and the rate of incidence of disease. Disease severity was estimated by measuring the extent of the lesions 25 days after inoculation. The area under the disease progress curve (AUDPC) and the rate of disease progress were calculated as described by Campbell and Madden (4) using the disease severity data, which were estimated by measuring the extent of lesions at day $13,16,19,22$, and 25 postinoculation. Five models were generated for this rate, as previously described by Campbell and Madden (4), and the Gompertz model was used as the representative model.

Pathogenicity to cashew seedlings and other hosts in the Anacardiaceae family. The pathogenicity to cashew and other hosts in the Anacardiaceae family of three pigmented strains of Xanthomonas (CCP76, TAQ13, TAQ18), one X. citri pv. anacardii strain (IBSBF1508), and one pigmented (IBSBF873) and one nonpigmented strain (IBSBF1230) identified as X. campestris pv. mangiferaeindicae (Table 1) was assayed. In separate experiments, the leaves of cashew (clone CCP76), mango (var. Kate), Brazilian pepper (Schinus terebinthifolius Raddi), and hog plum (Spondias mombin L.) seedlings, previously grown in a greenhouse, were inoculated using the infiltration method at six points along the surface of the leaf. We used the first four leaves from the apex of each seedling. The tests were conducted with four replicates per isolate in which each replicate consisted of one inoculated leaf, with the selection of seedlings, leaf, and inoculated isolate performed randomly. The seedlings were incubated in a greenhouse and pathogenicity was assessed based on the incubation period of the disease, incidence, severity, and AUDPC.

Experimental design and statistical analysis. All experiments were set up in a completely randomized design. There were no significant differences $(P<0.05)$ for the variance of replicates from the experiments conducted to evaluate inoculation methods, epidemiological components of cashew Xanthomonas leaf spot, or pathogenicity in other hosts of the Anacardiaceae family. Therefore, the data were analyzed as time replications. Transformations were made to meet the assumptions of the analysis of variance (ANOVA). We used the Tukey and Scott-Knott tests at a 5\% probability level to compare the means. The nonparametric KruskalWallis test at a 5\% probability level was used to analyze the experiments that did not achieve homogeneity of variance. Except for the
Scott-Knott test, which was done with SAEG (version 9.0, Universidade Federal de Viçosa, Brazil), the analyses were performed using SAS (version 9.1; SAS Institute, USA).

The analysis of the rep-PCR profiles obtained with ERIC and BOX primers were performed according to the presence (1) or absence $(0)$ of bands between 100 and $1,000 \mathrm{bp}$. The data from each primer were analyzed separately or combined using MVSP 3.1 (Kovach Computing Services, Wales). To determine the genetic relationships among the strains, we used the Jaccard similarity coefficient (26) and unweighted pair-group method using arithmetic averages (UPGMA) cluster analysis.

\section{Results}

Isolation, phenotypic characterization, and in vitro sensitivity to antibiotics and copper compounds used in agriculture. We isolated 66 nonpigmented and 42 pigmented strains from the leaves and fruit of cashew trees with symptoms characteristic of Xanthomonas spot. All 108 strains were inoculated on leaves of dwarf cashew clone CCP76; however, only 31 pigmented strains, 30 from the leaves and 1 from the fruit, were pathogenic and caused typical Xanthomonas spot symptoms (Table 1). X. citri pv. anacardii strains (IBSBF 1508 and IBSBF1971), causal agents of angular leaf spot on cashews, as well as the pigmented (IBSBF873) and nonpigmented (IBSBF657 and IBSBF1230) non-re-classified $(1,2) X$. campestris pv. mangiferaeindicae strains isolated from mango bacterial black spot, also caused Xanthomonas spot symptoms on cashew seedlings. Based on visual estimates, the pigmented strains of Xanthomonas TAQ18, TAQ13, and CCP76, causal agents of Xanthomonas spot on cashew, were characterized as very aggressive, aggressive, and less aggressive, respectively, and so were selected for studies on different temperatures, $\mathrm{pH}$ levels, salt concentrations, and pathogenicity to cashew seedlings and other hosts in the Anacardiaceae family. Two saprophytic strains, one pigmented (SAPA) and one nonpigmented (SAPC), were randomly selected and included in the molecular analysis for comparison of rep-PCR profiles. We did not observe any differences among the phenotypic profiles of strains we studied (Table 2). The optimum growth temperatures for the pigmented strains of Xanthomonas were $28^{\circ} \mathrm{C}$ for TAQ13 and TAQ18, and $29^{\circ} \mathrm{C}$ for CCP76. The growth of all three strains was best between $\mathrm{pH} 6$ and 7, with optimal growth seen at $\mathrm{pH}$ 6.5. All three strains showed tolerance up to $2 \% \mathrm{NaCl}$; there was no growth observed at $3 \% \mathrm{NaCl}$ and above.

All of the 31 pigmented strains of Xanthomonas, as well as $X$. citri pv. anacardii strains (IBSBF 1508 and IBSBF1971) and the pigmented (IBSBF873) and nonpigmented (IBSBF657 and IBSBF1230) $X$. campestris pv. mangiferaeindicae strains, were sensitive to commercial products with a base of copper oxychloride, copper hydroxide, oxytetracycline, oxytetracycline + tribasic copper sulfate, or streptomycin sulfate + oxytetracycline. All of the strains were resistant to kasugamycin. This last result was confirmed by use of Acidovorax citrulli strain Ac1.7 (Culture Collection of the Phytobacteriology Laboratory, Universidade Federal Rural de Pernambuco) as a positive control (i.e., sensitive to kasugamycin at the tested concentration of $60 \mathrm{mg} / \mathrm{liter}$ ).

rep-PCR analysis. All pigmented strains of Xanthomonas, one pigmented (IBSBF873) and two nonpigmented (IBSBF 657 and IBSBF1230) $X$. campestris pv. mangiferaeindicae strains, one $X$. axonopodis pv. spondiae strain (IBSBF2585), causal agent of angular leaf spot in Spondias spp. (1), three X. citri pv. anacardii strains (IBSBF 1508, IBSBF1971, and IBSBF2579), one $X$. citri pv. mangiferaeindicae strain (IBSBF2586), causal agent of bacterial black spot of mango, and two saprophytic strains obtained from cashew leafs with symptoms of Xanthomonas spot, one pigmented (SAPA) and one nonpigmented (SAPC), were fingerprinted using rep-PCR (Table 1). The rep-PCR fingerprint profiles, obtained with the BOX and ERIC primers (Fig. 1A and B, respectively), demonstrated that there was a high similarity between the pigmented strains of Xanthomonas, pigmented and nonpigmented $X$. campestris pv. mangiferaeindicae strains, and X. citri pv. ana- 
cardii strains. Despite several attempts, we were unable to amplify DNA from the strains using the REP1R-I and REP2-I primers.

Cluster analysis generated with the combined BOX and ERIC data (Fig. 2) agreed with the cluster analysis generated by the BOX or ERIC data individually (data not shown). We identified eight groups with a similarity level of $70 \%$. Groups I, II, III, and IV consisted of strains IBSBF2586 (X. citri pv. mangiferaeindicae), SAPC (saprophyte), SAPA (saprohyte), and IBSBF2585 (X. axonopodis pv. spondiae), respectively. Group $\mathrm{V}$ consisted of strain IBSBF2579 from $X$. citri pv. anacardii, the causal agent of angular leaf spot in cashew. Group VI consisted of nonpigmented, non-reclassified $(1,2) \quad X$. campestris pv. mangiferaeindicae strains (IBSBF657 and IBSBF1230) from mango bacterial black spot, and $X$. citri pv. anacardii strains (IBSBF 1508 and IBSBF1971). Group VII consisted of two pigmented strains from cashew trees with Xanthomonas spot (TAQ3 and TAQ9), and finally, group VIII consisted of the remaining pigmented strains from the cashew trees with Xanthomonas spot and the mango pigmented, non-re-classified $X$. campestris pv. mangiferaeindicae strain (IBSBF873). All of the pigmented strains of Xanthomonas, three $X$. citri pv. anacardii strains (IBSBF1508, IBSBF1971, and IBSBF2579), and the pigmented (IBSBF873) and nonpigmented strains (IBSBF657 and IBSBF1230) identified as $X$. campestris pv. mangiferaeindicae included in this study formed a single group with a similarity level above $52 \%$.

IS1595 sequence amplification. Three primer pairs were selected to amplify the IS 1595 sequence present in the genome of $X$.

Table 2. Biochemical and physiological characteristics of pigmented strains of Xanthomonas associated with Anacardiaceae host family

\begin{tabular}{|c|c|c|c|}
\hline Characteristics & $\begin{array}{l}\text { Pigmented } \\
\text { strains }^{\mathrm{w}}\end{array}$ & 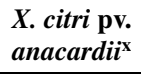 & $\begin{array}{c}\text { X. campestris pv. } \\
\text { mangiferaeindicae }\end{array}$ \\
\hline Gram & - & - & - \\
\hline Oxygen tolerance & Aerobic & Aerobic & Aerobic \\
\hline Color on YDC & Yellow & White & Yellow/white \\
\hline Growth on YDC at $33^{\circ} \mathrm{C}$ & $t^{\mathrm{z}}$ & + & + \\
\hline $\begin{array}{l}\text { Growth on tetrazolium } \\
\text { at } 0.1 \%\end{array}$ & - & - & - \\
\hline Catalase & - & - & - \\
\hline Oxidase & \pm & \pm & \pm \\
\hline $\begin{array}{l}\text { Fluorescent pigment on } \\
\text { KMB }\end{array}$ & - & - & - \\
\hline Indole production & - & - & - \\
\hline Oxidation/fermentation & Oxidative & Oxidative & Oxidative \\
\hline Starch hydrolysis & + & + & + \\
\hline Urea hydrolysis & - & - & - \\
\hline Casein hydrolysis & - & - & - \\
\hline Tween 80 hydrolysis & + & + & + \\
\hline Arginine hydrolysis & - & - & - \\
\hline Gelatin hydrolysis & + & + & + \\
\hline Cellulose hydrolysis & - & - & - \\
\hline \multicolumn{4}{|l|}{ Acid production } \\
\hline Cellobiose & + & + & + \\
\hline D-Arabinose & - & - & - \\
\hline D-Galactose & + & + & + \\
\hline D-Glucose & + & + & + \\
\hline D-Xylose & + & + & + \\
\hline L-Arginine & - & - & - \\
\hline Saccharose & + & + & + \\
\hline Sorbitol & + & + & + \\
\hline \multicolumn{4}{|l|}{ Carbohydrate utilization } \\
\hline Cellobiose & + & + & + \\
\hline D-Arabinose & - & - & - \\
\hline L-Arginine & - & - & - \\
\hline Saccharose & + & + & + \\
\hline $\begin{array}{l}\text { Hypersensitivity in } \\
\text { tobacco }\end{array}$ & + & + & + \\
\hline
\end{tabular}

w Pigmented strains of Xanthomonas causing Xanthomonas spot (Table 1).

${ }^{x}$ Strains obtained from angular leaf spots on cashew trees and reclassified by Ah-You et al. $(1,2)$ (IBSBF1508 and IBSBF1971).

${ }^{y}$ Nonpigmented (IBSBF657 and IBSBF1230) and pigmented strains (IBSBF873) obtained from mango bacterial black spot and not reclassified by Ah-You et al. $(1,2)$.

${ }^{\mathrm{z}}+$, Positive reaction; \pm , weak positive reaction; -, negative reaction. citri pv. mangiferaeindicae (IBSBF2586) with expected fragments ranging between 600 and 1,000 bp. Positive and reproducible amplification results were obtained only with the IS3F and IS3R primer pair, which produced a fragment between 900 and 1,000 bp, in agreement with the expected fragment size of $979 \mathrm{bp}$. This fragment was only detected in the IBSBF2586 strain.

Cashew leaf inoculation methods. Infiltration in the leaf blade was the most effective method for inoculating pigmented strains of Xanthomonas into cashew leaves (Table 3). We found that the incubation period for this method was significantly shorter $(P<0.05)$ than the incubation periods for the other methods tested, namely deposition in the midrib with injury, injection into the intermediary portion of the midrib, and spraying with injury. Furthermore, this method resulted in the highest rate of incidence and severity of disease, where these two variables differed just from the spraying without injury method.

Epidemiological components of Xanthomonas spot in cashew seedlings. Cluster analysis of the epidemiological components of Xanthomonas spot showed the formation of five groups of strains based on incubation period, three groups based on disease incidence, five groups based on disease severity, six groups based on the AUDPC, and five groups based on the rate of disease progress (Table 4).

Based on the data obtained from analysis of disease incidence, disease severity, AUDPC, and the rate of disease progress, groups $\mathrm{A}, \mathrm{B}$, and $\mathrm{C}$ contained the most virulent strains. These groups consisted of the pigmented strains of Xanthomonas, causal agents of Xanthomonas spot in cashew, pigmented (IBSBF873) and nonpigmented (IBSBF657 and IBSBF1230) strains isolated from mango bacterial black spots, identified as $X$. campestris pv. mangifer-

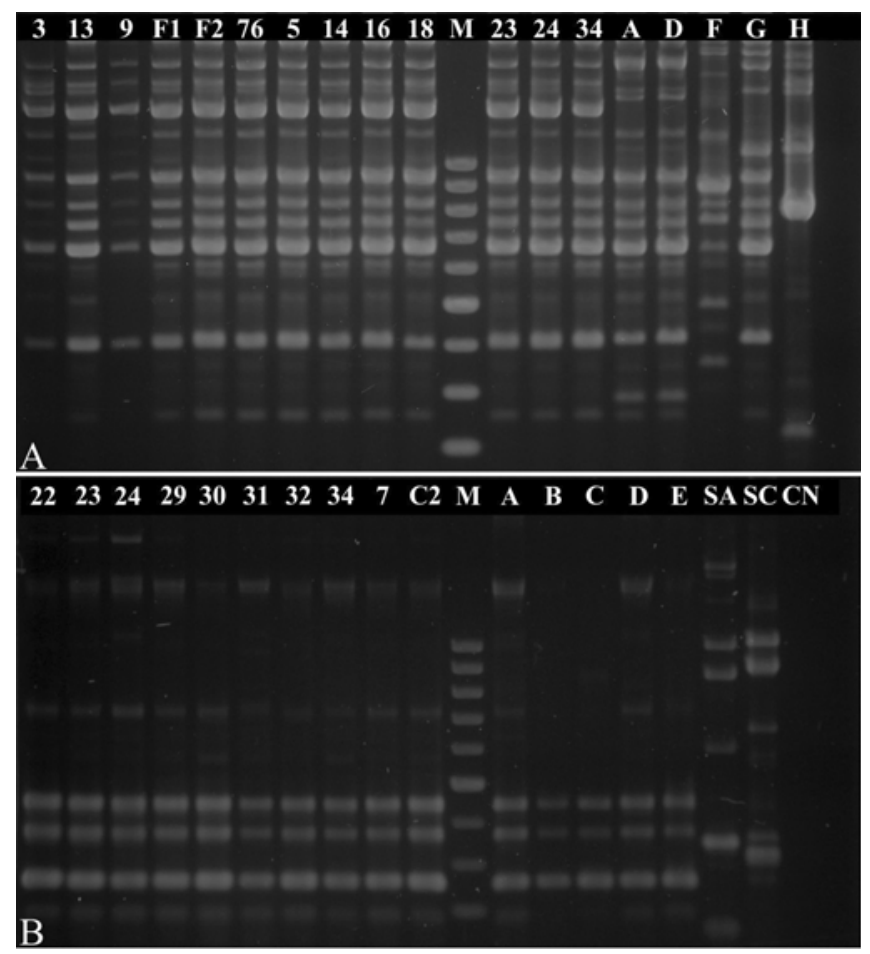

Fig. 1. Electrophoretic analysis of fragments generated by repetitive sequencebased polymerase chain reaction (rep-PCR) from the isolates used in this study. A, Profiles with BOX primer, B, profiles with ERIC primer. $\mathrm{M}=100$-bp DNA Ladder Marker (GenRuler). Lanes are designated as follows: (76) CCP76; (C2) CAST2; (F1) XCMF1; (F2) XCMF2; (1-34) TAQ1-TAQ34 (pigmented strains of Xanthomonas); (A) IBSBF1971, (B) IBSBF1508; (G) IBSBF2579 (pv. anacardii); (H) IBSBF2586 (pv. mangiferaeindicae); (F) IBSBF2585 (pv. spondiae); (C) IBSBF873 (pigmented strains of $X$. campestris pv. mangiferaeindicae isolated from the mango bacterial black spot and not reclassified [1,2]); (D) IBSBF657; (E) IBSBF1230 (nonpigmented strains of $X$. campestris pv. mangiferaeindicae isolated from the mango bacterial black spot and not reclassified [1,2]); (SA) yellow saprophyte (SAPA); (SC) cream-colored saprophytic bacterium (SAPC); (CN) negative controls. 
aeindicae, and not reclassified (1,2), and $X$. citri pv. anacardii strains (IBSBF1508 and IBSBF1971), causal agents of angular leaf spot in cashew trees. The remaining groups formed on these variables consisted of only pigmented strains. Based on data from only the incubation period, we observed clustering of some pigmented strains of Xanthomonas and X. citri pv. anacardii into group E, which had the shortest incubation period.

Pathogenicity to cashew seedlings and other Anacardiaceae hosts. All strains evaluated in this study: three pigmented strains of Xanthomonas (TAQ13, TAQ18, and CCP76), one X. citri pv. anacardii strain (IBSBF1508), one pigmented (IBSBF873) and one nonpigmented (IBSBF1230) strain identified as $X$. campestris pv. mangiferaeindicae, were pathogenic to Brazilian pepper, dwarf cashew (clone CCP76), and mango cv. Kate, with symptoms observed 3 days after inoculation. We observed on Brazilian pepper irregularly shaped brown spots. On the cashew seedlings, we observed small irregular brownish oily spots, which spread and, in some cases, reached secondary veins. After 25 days, the lesions had reached the midrib, petiole, and stem of the plant, which led to extensive dry necrosis of twigs and their tips. In addition, we observed the presence of bacterial exudate in
Table 3. Efficiency of the methods used for inoculating the pigmented Xanthomonas strain TAQ18 into leaves of the dwarf cashew seedlings (clone CCP76) and evaluated for the epidemiological components of the disease

\begin{tabular}{lccc}
\hline Inoculation method & $\begin{array}{c}\text { Incubation } \\
\text { period (days) }^{\mathbf{w}}\end{array}$ & $\begin{array}{c}\text { Incidence } \\
(\mathbf{\%})^{\mathbf{x}}\end{array}$ & $\begin{array}{c}\text { Severity } \\
\left(\mathbf{m m}^{\mathbf{2}} \mathbf{y}^{\mathbf{y}}\right.\end{array}$ \\
\hline $\begin{array}{l}\text { Deposition in the midrib with } \\
\text { injury }\end{array}$ & $24.50 \mathrm{a}^{\mathrm{z}}$ & $12.50 \mathrm{~b}$ & $2.98 \mathrm{ab}$ \\
$\begin{array}{l}\text { Spraying without injury } \\
\begin{array}{l}\text { Injection into the intermediary } \\
\text { portion of the midrib }\end{array}\end{array}$ & $16.75 \mathrm{ab}$ & $12.50 \mathrm{~b}$ & $0.04 \mathrm{~b}$ \\
$\begin{array}{l}\text { Spraying with injury } \\
\text { Infiltration in the leaf blade }\end{array}$ & $25.62 \mathrm{a}$ & $25.00 \mathrm{ab}$ & $17.24 \mathrm{ab}$ \\
\hline
\end{tabular}

${ }^{\mathrm{w}}$ Incubation period: number of days from inoculation to the appearance of the first symptoms.

${ }^{\mathrm{x}}$ Incidence: percentage of leaves or inoculation points showing disease symptoms 25 days after inoculation.

${ }^{y}$ Severity: estimated 25 days after inoculations using the software APS Assess.

${ }^{z}$ Average of eight replicates. Averages followed by the same letter in the column do not differ significantly, as measured by the Kruskal-Wallis test $(P<0.05)$.

UPGMA

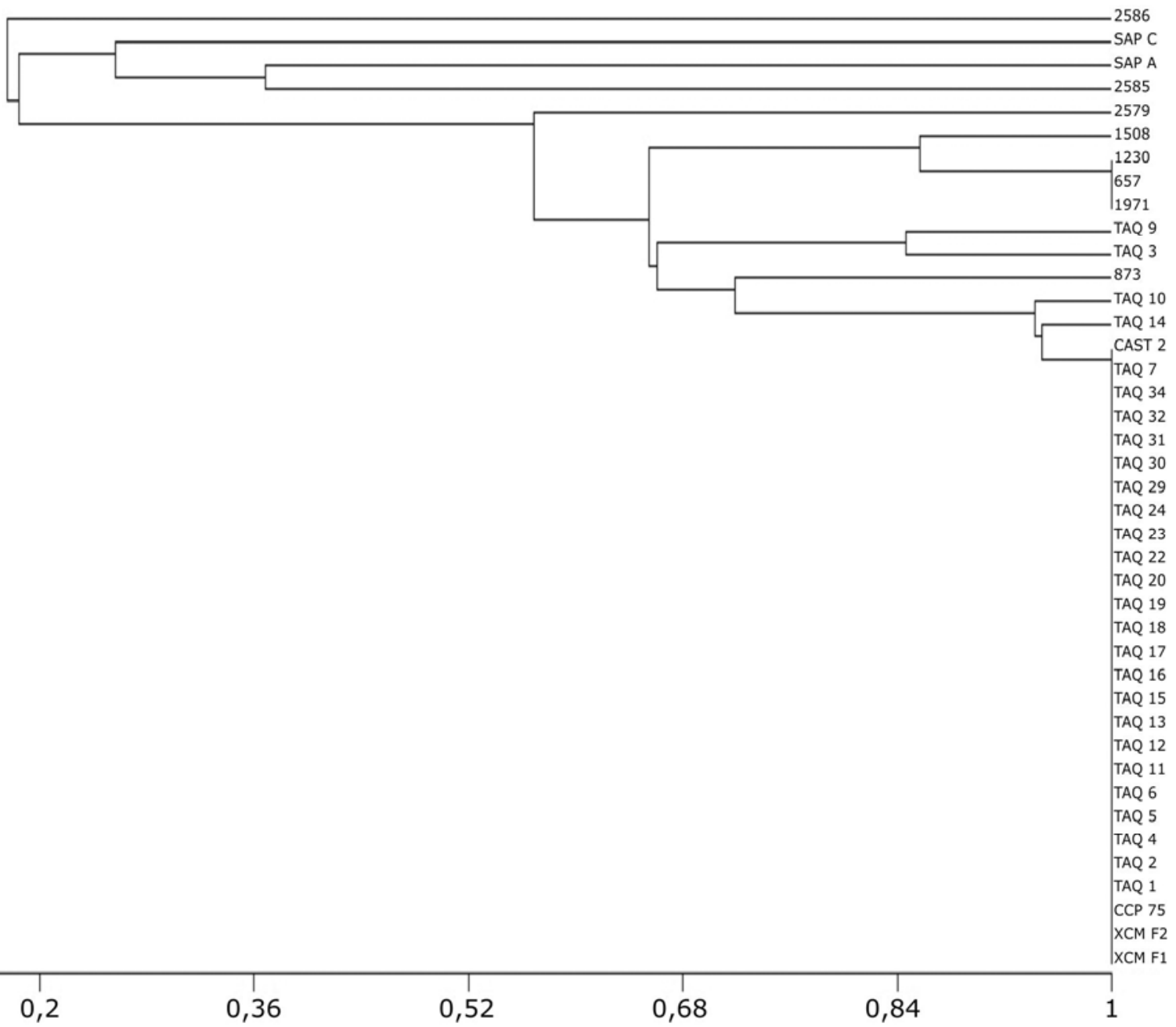

\begin{tabular}{rrrrrr|r|}
\hline 0,04 & 0,2 & 0,36 & 0,52 & 0,68 & 0,84 & 1 \\
\hline
\end{tabular}

\section{Jaccard's Coefficient}

Fig. 2. Dendrogram based on the unweighted pair-group method using arithmetic averages (UPGMA) according to the profiles generated by BOX and ERIC-PCR showing the relationships among: pigmented strains of Xanthomonas responsible for Xanthomonas spot on cashew trees; pigmented (IBSBF873) and nonpigmented (IBSBF657 and IBSBF1230) strains responsible for mango bacterial black spot, not reclassified by Ah-You et al. (1,2), and also X. citri pv. mangiferaeindicae (IBSBF2586), $X$. citri pv. anacardii (IBSBF1508, IBSBF1971, and IBSBF2579), and X. axonopodis pv. spondiae (IBSBF2585) reclassified by Ah-You et al. $(1,2)$. 
some stem lesions. Interestingly, the pigmented strains of Xanthomonas (CCP76, TAQ13, and TAQ18), X. citri pv. anacardii strain (IBSBF1508), as well as pigmented (IBSBF873) and nonpigmented (IBSBF1230) X. campestris pv. mangiferaeindicae strains, were able to induce both symptoms of angular leaf spot and Xanthomonas spot on cashew leaves (Fig. 3A and B, respectively). In mango, initially we observed small oily spots on the abaxial surface of the leaves. These spots progressed into irregular brownish lesions bound by the veins which could be observed on both sides of the leaf, and the lesions remained this way until the end of the experimental period, independent of the strain.

In Brazilian pepper, CCP76 significantly differed $(P<0.05)$ from the other strains, featuring longest incubation period and lowest disease incidence, severity, and AUDPC (Table 5). In cashew and mango, we observed similar behavior of the strains for all the variables evaluated. Only strains TAQ13, TAQ18, IBSBF1230, and IBSBF1508 were pathogenic in hog plum, but exhibited no differences in their symptoms. We observed the initial symptoms 4 days after inoculation, and they consisted of dark, irregular oily spots. There were no significant differences among these strains for the variables evaluated.

\section{Discussion}

Of the 108 strains (66 nonpigmented and 42 pigmented) isolated from leaves and fruits of cashew trees with Xanthomonas spot, 31 pigmented strains of Xanthomonas were pathogenic, thus demonstrating the occurrence of pigmented pathogenic Xanthomonas in orchards in the states of Ceará, Piauí, and São Paulo. The 66 nonpigmented and the 11 remaining pigmented strains that did not cause disease in cashew seedlings were considered saprophytes. Pathogenicity tests performed in cashew leaves with pigmented Xanthomonas, X. citri pv. anacardii (IBSBF1508 and IBSBF1971), causal agent of angular leaf spot in cashew, and pigmented (IBSBF873) and nonpigmented (IBSBF657 and IBSBF1230) strains obtained from mango bacterial black spot, which were identified as $X$. campestris pv. mangiferaeindicae and not reclassified by Ah-You et al. $(1,2)$, produced symptoms typical of Xanthomonas spot. These results support a close relationship among these strains, independent of the host of origin.

The phenotypic profiles of pigmented Xanthomonas strains were similar to the profiles of $X$. citri pv. anacardii strains (IBSBF1508 and IBSBF1971), X. campestris pv. mangiferaeindicae pigmented (IBSBF873) and nonpigmented strains (IBSBF657 and

Table 4. Epidemiological characterization of the angular leaf spot caused by pigmented Xanthomonas, X. citri pv. anacardii strains, and nonidentified strains associated with mango trees, which were artificially inoculated into leaves of dwarf cashew seedlings (clone CCP76) by the leaf infiltration method

\begin{tabular}{|c|c|c|c|c|c|}
\hline Strains & $\begin{array}{l}\text { Incubation period } \\
\left(_{(\text {days })^{\mathrm{s}, t}}\right.\end{array}$ & $\begin{array}{l}\text { Incidence } \\
\qquad(\%)^{\mathrm{u}}\end{array}$ & $\begin{array}{l}\text { Severity } \\
\left(\mathbf{m m}^{2}\right)^{\mathbf{v}, t}\end{array}$ & $\begin{array}{l}\text { Area under the disease } \\
\text { progression curvew }^{w}\end{array}$ & $\begin{array}{l}\text { Rate of disease } \\
\text { progression }^{x, t}\end{array}$ \\
\hline TAQ1 & $13.58 \mathrm{~b}^{\mathrm{y}}$ & $79.17 \mathrm{~b}$ & $48.30 \mathrm{~d}$ & $68.87 \mathrm{e}$ & $0.0053 \mathrm{c}$ \\
\hline TAQ2 & $6.33 \mathrm{~d}$ & $100.00 \mathrm{a}$ & $50.02 \mathrm{~d}$ & $101.70 \mathrm{c}$ & $0.0034 \mathrm{~d}$ \\
\hline TAQ3 & $16.00 \mathrm{~b}$ & $50.00 \mathrm{c}$ & $2.99 \mathrm{e}$ & $18.70 \mathrm{f}$ & $0.0011 \mathrm{e}$ \\
\hline TAQ4 & $4.00 \mathrm{e}$ & $100.00 \mathrm{a}$ & $65.59 \mathrm{c}$ & $114.68 \mathrm{~b}$ & $0.0036 \mathrm{c}$ \\
\hline TAQ5 & $7.50 \mathrm{c}$ & $75.00 \mathrm{~b}$ & $23.55 \mathrm{e}$ & $55.37 \mathrm{e}$ & $0.0030 \mathrm{~d}$ \\
\hline TAQ6 & $17.83 \mathrm{~b}$ & $45.83 \mathrm{c}$ & $2.15 \mathrm{e}$ & $15.10 \mathrm{f}$ & $0.0005 \mathrm{e}$ \\
\hline TAQ7 & $7.08 \mathrm{c}$ & $100.00 \mathrm{a}$ & $42.32 \mathrm{~d}$ & $77.64 \mathrm{~d}$ & $0.0046 \mathrm{c}$ \\
\hline TAQ9 & $5.88 \mathrm{~d}$ & $100.00 \mathrm{a}$ & $38.90 \mathrm{~d}$ & $82.64 \mathrm{~d}$ & $0.0032 \mathrm{~d}$ \\
\hline TAQ10 & $3.96 \mathrm{e}$ & $100.00 \mathrm{a}$ & $46.71 \mathrm{~d}$ & $101.28 \mathrm{c}$ & $0.0026 \mathrm{~d}$ \\
\hline TAQ11 & $21.71 \mathrm{a}$ & $20.83 \mathrm{c}$ & $0.43 \mathrm{e}$ & $5.22 \mathrm{f}$ & $0.0002 \mathrm{e}$ \\
\hline TAQ12 & $5.38 \mathrm{~d}$ & $100.00 \mathrm{a}$ & $57.42 \mathrm{c}$ & $85.47 \mathrm{~d}$ & $0.0051 \mathrm{c}$ \\
\hline TAQ13 & $3.79 \mathrm{e}$ & $100.00 \mathrm{a}$ & $70.55 \mathrm{c}$ & $117.78 \mathrm{~b}$ & $0.0038 \mathrm{c}$ \\
\hline TAQ14 & $3.88 \mathrm{e}$ & $79.17 \mathrm{~b}$ & $23.55 \mathrm{e}$ & $63.33 \mathrm{e}$ & $0.0024 \mathrm{~d}$ \\
\hline TAQ15 & $3.38 \mathrm{e}$ & $100.00 \mathrm{a}$ & $84.74 b$ & $126.88 \mathrm{~b}$ & $0.0042 \mathrm{c}$ \\
\hline TAQ16 & $3.83 \mathrm{e}$ & $100.00 \mathrm{a}$ & $90.02 \mathrm{~b}$ & $123.89 \mathrm{~b}$ & $0.0051 \mathrm{c}$ \\
\hline TAQ17 & $2.87 \mathrm{e}$ & $100.00 \mathrm{a}$ & $86.74 \mathrm{~b}$ & $123.26 \mathrm{~b}$ & $0.0048 \mathrm{c}$ \\
\hline TAQ18 & $2.79 \mathrm{e}$ & $100.00 \mathrm{a}$ & $139.34 \mathrm{a}$ & $156.39 \mathrm{a}$ & $0.0064 \mathrm{~b}$ \\
\hline TAQ19 & $17.79 \mathrm{~b}$ & $41.67 \mathrm{c}$ & $4.89 \mathrm{e}$ & $23.20 \mathrm{f}$ & $0.0012 \mathrm{e}$ \\
\hline TAQ20 & $5.75 \mathrm{~d}$ & $100.00 \mathrm{a}$ & $49.47 \mathrm{~d}$ & $97.41 \mathrm{c}$ & $0.0043 \mathrm{c}$ \\
\hline TAQ22 & $4.13 \mathrm{e}$ & $95.83 \mathrm{a}$ & $68.95 \mathrm{c}$ & $109.18 \mathrm{c}$ & $0.0041 \mathrm{c}$ \\
\hline TAQ23 & $4.58 \mathrm{e}$ & $100.00 \mathrm{a}$ & $31.88 \mathrm{e}$ & $88.51 \mathrm{~d}$ & $0.0026 \mathrm{~d}$ \\
\hline TAQ24 & $5.21 \mathrm{~d}$ & $100.00 \mathrm{a}$ & $36.80 \mathrm{~d}$ & $87.16 \mathrm{~d}$ & $0.0025 \mathrm{~d}$ \\
\hline TAQ29 & $4.46 \mathrm{e}$ & $100.00 \mathrm{a}$ & $43.78 \mathrm{~d}$ & $97.10 \mathrm{c}$ & $0.0036 \mathrm{c}$ \\
\hline TAQ30 & $8.37 \mathrm{c}$ & $95.83 \mathrm{a}$ & $29.41 \mathrm{e}$ & $62.31 \mathrm{e}$ & $0.0041 \mathrm{c}$ \\
\hline TAQ31 & $4.08 \mathrm{e}$ & $37.50 \mathrm{c}$ & $2.29 \mathrm{e}$ & $5.98 \mathrm{f}$ & $0.0007 \mathrm{e}$ \\
\hline TAQ32 & $7.61 \mathrm{c}$ & $72.22 b$ & $20.80 \mathrm{e}$ & $57.22 \mathrm{e}$ & $0.0096 \mathrm{a}$ \\
\hline TAQ34 & $9.41 \mathrm{c}$ & $87.50 \mathrm{~b}$ & $15.09 \mathrm{e}$ & $42.62 \mathrm{e}$ & $0.0030 \mathrm{~d}$ \\
\hline XCMF1 & $4.70 \mathrm{~d}$ & $100.00 \mathrm{a}$ & $52.60 \mathrm{~d}$ & $113.14 \mathrm{~b}$ & $0.0039 \mathrm{c}$ \\
\hline XCMF2 & $4.67 \mathrm{e}$ & $100.00 \mathrm{a}$ & $40.96 \mathrm{~d}$ & $85.84 \mathrm{~d}$ & $0.0039 \mathrm{c}$ \\
\hline ССР76 & $4.17 \mathrm{e}$ & $87.50 \mathrm{~b}$ & $21.14 \mathrm{e}$ & $63.80 \mathrm{e}$ & $0.0019 \mathrm{~d}$ \\
\hline CAST2 & $6.61 \mathrm{~d}$ & $95.83 \mathrm{a}$ & $73.26 \mathrm{c}$ & $105.14 \mathrm{c}$ & $0.0048 \mathrm{c}$ \\
\hline IBSBF873 & $6.25 \mathrm{~d}$ & $87.50 \mathrm{~b}$ & $54.55 \mathrm{~d}$ & $107.27 \mathrm{c}$ & $0.0037 \mathrm{c}$ \\
\hline IBSBF657 & $3.13 \mathrm{e}$ & $100.00 \mathrm{a}$ & $129.87 \mathrm{a}$ & $153.84 \mathrm{a}$ & $0.0062 \mathrm{~b}$ \\
\hline IBSBF1230 & $4.54 \mathrm{e}$ & $100.00 \mathrm{a}$ & $81.01 \mathrm{~b}$ & $124.18 \mathrm{~b}$ & $0.0049 \mathrm{c}$ \\
\hline IBSBF1508 & $4.17 \mathrm{e}$ & $100.00 \mathrm{a}$ & $124.64 \mathrm{a}$ & $150.53 \mathrm{a}$ & $0.0059 \mathrm{~b}$ \\
\hline IBSBF1971 & $3.71 \mathrm{e}$ & $100.00 \mathrm{a}$ & $92.06 \mathrm{~b}$ & $124.57 \mathrm{~b}$ & $0.0079 \mathrm{a}$ \\
\hline $\mathrm{VC}^{\mathrm{z}}(\%)$ & 17.88 & 18.39 & 21.30 & 22.07 & 0.21 \\
\hline
\end{tabular}

s Incubation period: number of days from inoculation to appearance of first symptoms.

${ }^{t}$ Data transformed into $\sqrt{ } x+0.5$

u Incidence: percentage of leaves or inoculation points showing disease symptoms 25 days after inoculation.

v Severity: evaluated by measuring lesion extension 25 days after inoculation.

${ }^{\mathrm{w}}$ Area under the disease progress curve.

${ }^{x}$ Rate of disease progress: represented by Gompertz model, calculated according to Campbell and Madden (4).

y Average of eight replicates. Averages followed by the same letter in the column are not significantly different, as measured by Scott-Knott test $(P<0.05)$

z VC: variation coefficient. 
IBSBF1230). However, we observed some differences between the profiles generated in this study and those shown in other studies. Pruvost et al. (19) described pathovars of Xanthomonas citri associated with the Anacardiaceae family as being oxidase negative and casein hydrolysis positive. However, the strains analyzed in this study were weakly positive for oxidase and were unable to hydrolyze casein. Our results agree with those obtained by Steyn et al. (27). However, in contrast to the results obtained by Pruvost et al. (19), Steyn et al. (27), and Manicon and Wallis (11), none of the strains that we tested were able to hydrolyze cellulose.

The growth conditions for the three pigmented Xanthomonas strains (CCP76, TAQ13, and TAQ18) were similar to those observed by Pruvost et al. (19), who showed growth in up to $2 \%$ $\mathrm{NaCl}$, and by Patel et al. (17), who observed optimum growth at $27^{\circ} \mathrm{C}$.

Given that Xanthomonas spot is a recent disease expanding into different regions of Brazil $(15,30)$, we analyzed the sensitivity of some pigmented pathogenic strains to antibiotics and copper compounds used in agriculture to control diseases affecting cashew trees and other plants belonging to the Anacardiaceae family as well as diseases caused by other species or pathovars of Xanthomonas (http://extranet.agricultura.gov.br/agrofit_cons/principal_agro fit_cons).

We found that all pigmented strains of Xanthomonas, X. citri pv. anacardii strains (IBSBF1508 and IBSBF1971), and the pigmented (IBSBF873) and nonpigmented (IBSBF657 and IBSBF1230) $X$. campestris pv. mangiferaeindicae strains are resistant only to kasugamycin (60 mg/liter), suggesting a close relationship among them. This fact indicates a possible exposure of strains to the antibiotic or the presence of constitutive resistance encoded on chromosomal or plasmid DNA.

Pruvost et al. (19) also observed resistance to 64 to $128 \mathrm{mg} / \mathrm{liter}$ of kasugamycin in their collection of nonpigmented Xanthomonas strains associated with the Anacardiaceae family. Taken together, these results suggest the presence of constitutive resistance because the application of antibiotics is not common in mango and cashew plantations. The sensitivity of other Xanthomonas species to antibiotics and copper has also been demonstrated. For example, Quezado-Duval et al. (20) reported sensitivity to copper sulfate and oxytetracycline at $200 \mathrm{mg} /$ liter when evaluating a collection of 389 Xanthomonas spp. strains associated with tomato plants.

Cluster analysis of the ERIC and BOX PCR profiles showed that all strains associated with cashew trees, including the three $X$. citri pv. anacardii strains used in this study, formed a single group with a similarity level above $52 \%$. These results indicate a close association regardless of the presence or absence of pigment. At a similarity level of $70 \%$, strains were divided into eight groups, allowing us to differentiate among the pigmented strains of Xanthomonas, $X$. citri pv. anacardii, $X$. citri pv. mangiferaeindicae, $X$. axonopodis pv. spondiae, or the saprophytic strains. Except for two strains (TAQ3 and TAQ9), all pigmented strains of Xanthomonas, causal agents of Xanthomonas spot, formed a single cluster with $100 \%$ similarity (Group VIII), suggesting low variability. Altogether, these data indicate that these pigmented strains of Xanthomonas are closely related to $X$. citri pv. anacardii and may be variants of this pathovar with higher aggressiveness toward cashew trees. Additionally, nonpigmented $X$. campestris pv. mangiferaeindicae strains (IBSBF657 and IBSBF1230) and one X. citri pv. anacardii strain (IBSBF1971) formed a single cluster at a similarity level of $100 \%$, indicating that possibly these strains belong to the same pathovar. However, further studies are needed to verify this hypothesis.

Trindade et al. (28) detected polymorphisms in strains of $X$. campestris pv. mangiferaeindicae (pigmented and nonpigmented strains of Xanthomonas from cashew with angular leaf spot and mango trees with bacterial black spot symptoms non-re-classified for Ah-You et al. [1,2]) and X. campestris pv. viticola. Digesting PCR products amplified with the RST2/Xcv3R primers used for
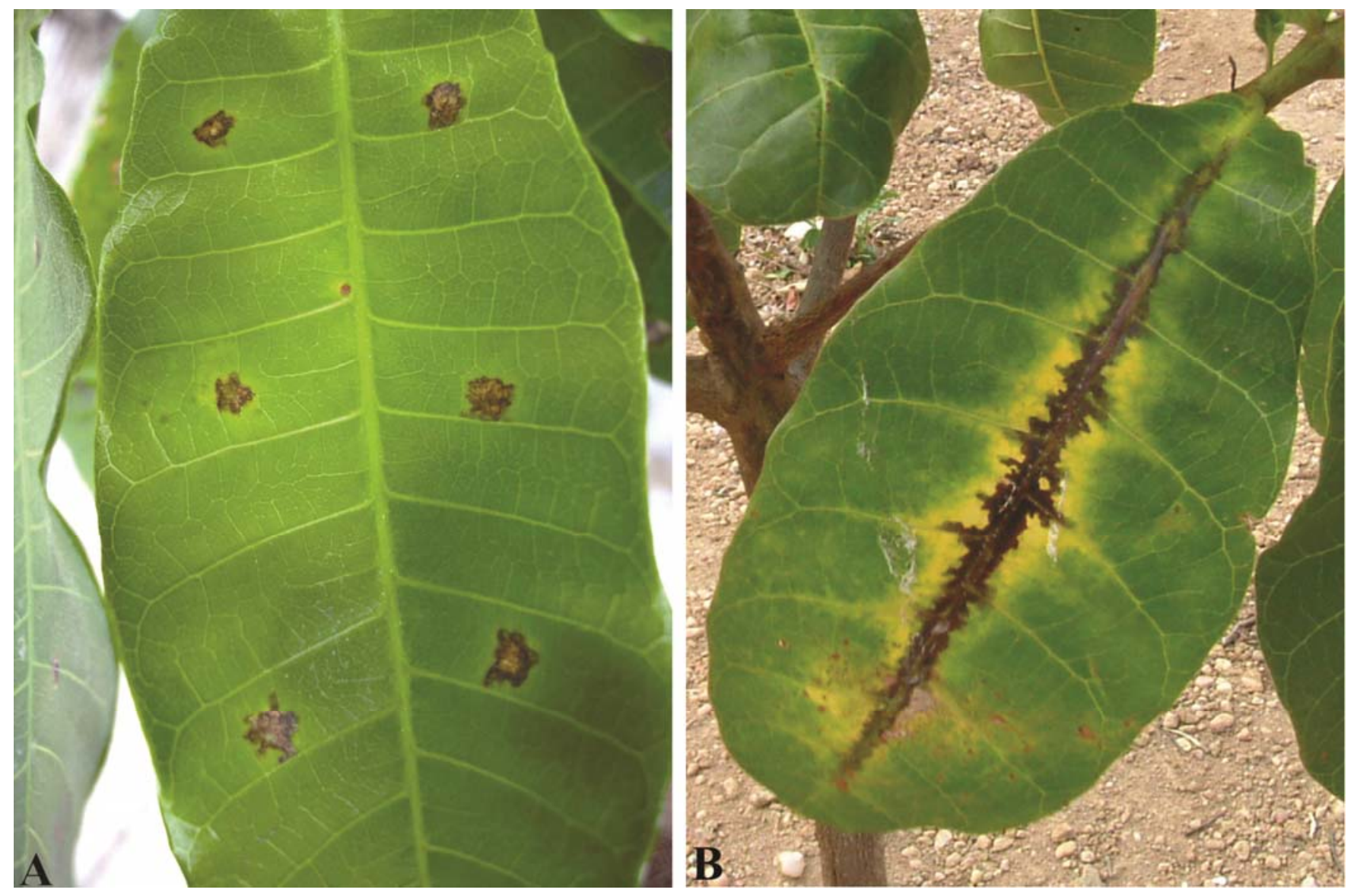

Fig. 3. Leaf lesions caused by pigmented strains of Xanthomonas. A, Characteristic symptom of angular leaf spot, and B, characteristic symptom of Xanthomonas spot. 
identifying pv. viticola, with HaeIII generated distinct patterns for both pathovars, with two restriction patterns observed for $X$. campestris pv. mangiferaeindicae.

Pigmented strains of Xanthomonas associated with mango trees have been detected in South Africa, Brazil, Florida, and Réunion Island (7), whereas both pigmented and nonpigmented strains that cause disease in cashew trees have only been reported in Brazil (1). Based on this fact and on the data generated by BOX and ERIC PCR, which show that there is a close similarity between pigmented strains of Xanthomonas, causal agents of Xanthomonas spot in cashew, and $X$. citri pv. anacardii, causal agent of angular leaf spot in cashew, we hypothesize that in Brazil these strains have co-evolved together in the same host (cashew trees). Furthermore, it is possible that the pigmented strains of Xanthomonas originated in Brazil, as this is the only country where these strains have been reported to cause disease in cashew trees $(29,30,32)$. Since pigmented strains of Xanthomonas are casual pathogens in mango (1), another hypothesis is that these strains were introduced into Brazil in contaminated but symptomless mango trees and subsequently disseminated to cashew trees. These strains likely remained innocuous to the cashew trees until conditions became favorable for the development of the disease, i.e., until giant cashew tree orchards were replaced with dwarf cashew tree orchards from one single clone (CCP76) (32). This may have been the key trigger that led to epidemic outbreaks in commercial cashew orchards.

Even though the majority of pigmented strains formed one group with $100 \%$ similarity, we did not observe a correlation with geographic origin, allowing us to infer that there was a recent introduction of these strains into São Paulo. Given that Ceará and Piauí are the main producers of cashews among the Brazilian states, a possible distribution of dwarf cashew seedlings to the state of São Paulo, where the disease was first observed in 2009, would support this possibility.

According to Ah-You et al. (1), X. citri pv. mangiferaeindicae strains have several insertion elements of the IS1595 family, whereas $X$. citri pv. anacardii and $X$. axonopodis pv. spondiae strains do not contain this element in their genomes. Although we designed three primer pairs, we could only amplify a fragment from the IS1595 sequence with the IS3F/IS3R primer pair, which amplifies a 979-bp fragment. This amplification was used to distinguish $X$. citri pv. mangiferaeindicae (IBSBF2586) from the remaining strains. Therefore, this primer pair could be used as a tool for diagnosis and control purposes based on the exclusion principle.

Phytobacteriology studies involving etiology, epidemiology, and control often require effective inoculation methods that must be practical, inexpensive, and highly reproducible both in greenhouses and in the field (9). Therefore, to assess the epidemiological components of Xanthomonas spot in artificially inoculated cashew trees, we needed to establish an appropriate inoculation method to reproduce the symptoms of the disease and to study the epidemiology of this disease. In the experiments to evaluate inoculation methods in leaves of cashew, there was a high variability within treatments, which may have been caused by low efficacy of some methods and/or by the low number of replicates. Among the inoculation methods evaluated, the infiltration in the leaf blade was the most suitable as it allowed the formation of lesions that could be easily quantified in addition to enabling the spread of these lesions to the secondary veins and then to the primary ribs, thus reproducing the characteristic symptoms of Xanthomonas spot.

Our evaluation of the epidemiological components of Xanthomonas spot in artificially inoculated cashew seedlings indicated that pigmented Xanthomonas strains TAQ13, TAQ18, and CCP76 and strains IBSBF1508, IBSBF1971, IBSBF873, IBSBF657, and IBSBF1230 are closely related, similarly aggressive, and show specificity toward cashew trees.

We were unable to observe any obvious differences between the symptoms caused by strains that cause angular leaf spot and Xanthomonas spot when they were inoculated onto different hosts. However, the strains used in this study proved to be more aggres-

Table 5. Epidemiological characterization of angular leaf spot caused by pigmented strains of Xanthomonas, X. citri pv. anacardii, and nonidentified strains associated with mango trees, which were artificially inoculated into leaves of Brazilian pepper, dwarf cashew seedlings (clone CCP76), and mango cv. Kate using the leaf infiltration method

\begin{tabular}{|c|c|c|c|c|}
\hline Strains & Incubation period (days) $^{t}$ & Incidence $(\%)^{\mathrm{u}}$ & Severity $\left(\mathrm{mm}^{2}\right)^{v}$ & AUDPC $^{w}$ \\
\hline \multicolumn{5}{|c|}{ Brazilian pepper } \\
\hline TAQ13 & $3.14 c^{x, y}$ & $93.75 \mathrm{a}$ & $66.61 \mathrm{a}$ & $12.63 \mathrm{ab}$ \\
\hline TAQ18 & $3.86 \mathrm{c}$ & $91.67 \mathrm{a}$ & $55.50 \mathrm{a}$ & $9.65 \mathrm{~b}$ \\
\hline ССР76 & $21.25 \mathrm{a}$ & $23.81 \mathrm{~b}$ & $9.69 \mathrm{~b}$ & $0.96 \mathrm{c}$ \\
\hline IBSBF873 & $5.11 \mathrm{bc}$ & $95.83 \mathrm{a}$ & $59.02 \mathrm{a}$ & $11.20 \mathrm{ab}$ \\
\hline IBSBF1230 & $9.05 \mathrm{~b}$ & $100 \mathrm{a}$ & $71.75 \mathrm{a}$ & $14.83 \mathrm{a}$ \\
\hline IBSBF1508 & $4.89 \mathrm{bc}$ & $95.23 \mathrm{a}$ & $55.23 \mathrm{a}$ & $9.29 \mathrm{~b}$ \\
\hline $\mathrm{VC}^{\mathrm{z}}(\%)$ & 25.23 & 18.65 & 22.63 & 33.74 \\
\hline \multicolumn{5}{|c|}{ Cashew clone CCP76 } \\
\hline TAQ13 & $3.38 \mathrm{a}^{\mathrm{y}}$ & $100 \mathrm{a}$ & $50.37 \mathrm{abc}$ & $111.79 \mathrm{ab}$ \\
\hline TAQ18 & $3.14 \mathrm{a}$ & $100 \mathrm{a}$ & $79.20 \mathrm{a}$ & $126.94 \mathrm{a}$ \\
\hline ССР76 & $6.24 \mathrm{a}$ & $95.83 \mathrm{a}$ & $32.49 \mathrm{c}$ & $86.97 \mathrm{~b}$ \\
\hline IBSBF873 & $4.01 \mathrm{a}$ & $100 \mathrm{a}$ & $42.51 \mathrm{bc}$ & $102.81 \mathrm{ab}$ \\
\hline IBSBF1230 & $5.62 \mathrm{a}$ & $100 \mathrm{a}$ & $73.49 \mathrm{a}$ & $123.44 \mathrm{a}$ \\
\hline IBSBF1508 & $6.54 \mathrm{a}$ & $93.75 \mathrm{a}$ & 77.49 a & $118.61 \mathrm{ab}$ \\
\hline $\mathrm{VC}^{\mathrm{z}}(\%)$ & 64.88 & 8.01 & 37.41 & 20.87 \\
\hline \multicolumn{5}{|c|}{ Mango cv. Kate } \\
\hline TAQ13 & $5.93 b^{y}$ & $100 \mathrm{a}$ & $27.05 \mathrm{a}$ & $87.22 \mathrm{a}$ \\
\hline TAQ18 & $7.55 \mathrm{a}$ & $92.86 \mathrm{a}$ & $13.79 \mathrm{ab}$ & $61.58 \mathrm{ab}$ \\
\hline ССР76 & $11.91 \mathrm{a}$ & $79.16 \mathrm{a}$ & $6.56 \mathrm{~b}$ & $38.71 \mathrm{~b}$ \\
\hline IBSBF873 & $6.90 \mathrm{a}$ & $85.42 \mathrm{a}$ & $24.95 \mathrm{a}$ & $75.42 \mathrm{a}$ \\
\hline IBSBF1230 & $6.44 \mathrm{a}$ & $100 \mathrm{a}$ & $28.38 \mathrm{a}$ & $89.77 \mathrm{a}$ \\
\hline IBSBF1508 & $8.27 \mathrm{a}$ & $95.83 \mathrm{a}$ & $18.87 \mathrm{ab}$ & $72.55 \mathrm{a}$ \\
\hline $\mathrm{VC}^{\mathrm{z}}(\%)$ & 50.53 & 18.63 & 55.91 & 31.27 \\
\hline
\end{tabular}

${ }^{\mathrm{t}}$ Incubation period: number of days from inoculation to appearance of the first symptoms.

${ }^{\mathrm{u}}$ Incidence: percentage of inoculation points showing disease symptoms.

${ }^{v}$ Severity: evaluated by measuring lesion extension 25 days after inoculation.

${ }^{w}$ Area under the disease progress curve: calculated according to Campbell and Madden (4).

${ }^{x}$ Data transformed into $\log x+0.5$

${ }^{y}$ Average of eight replicates. Averages followed by the same letter in the column are not significantly different, as measured by Tukey's test $(P<0.05)$.

${ }^{z}$ VC: variation coefficient. 
sive toward cashew seedlings than toward mango, Brazilian pepper, and hog plum seedlings, which further confirms their specificity to cashew trees. The lesions seen on the Brazilian pepper seedlings were less severe than those seen on mango seedlings, as observed by the slow progression of the disease and illustrated by the smaller AUDPC. In hog plum seedlings, only strains TAQ13, TAQ18, IBSBF1230, and IBSBF1508 caused lesions and were less aggressive, indicating a lower susceptibility of this host to Xanthomonas strains associated with the Anacardiaceae family. These results are in agreement with those reported by Ah-You et al. (1). The strains IBSBF873, TAQ13, and TAQ18 were as aggressive to mango plants as the nonpigmented IBSBF1230 from mango tree and $X$. citri pv. anacardii (IBSBF1508). These results partially disagree with data from Pruvost (18), who found that pigmented strains are less aggressive toward mango trees than nonpigmented strains.

Based on several results from this study, we conclude that pigmented strains of Xanthomonas causing Xanthomonas spot in cashew trees in Brazil are very aggressive in this host and should not be considered casual pathogens. Based on our phenotypic, molecular, and pathogenic results, we conclude that these strains do not differ from $X$. citri pv. anacardii, but may be a variant of this pathovar. However, further studies are needed to clarify the taxonomic relationship of these strains.

\section{Acknowledgments}

We thank the National Council for Scientific and Technological Development (CNPq) for the scholarships awarded to Marco Aurélio S. Gama, Elineide B. Silveira, Rosa L. R. Mariano, and Marisa A. S. V. Ferreira. We thank J. Rodrigues Neto (Phytobacteria Culture Collection of Instituto Biológico, São Paulo, Brazil) for providing the strains IBSBF, Cynthia M. Kyaw (Cell Biology Department, Universidade de Brasília, Brasília, Brazil) for assistance in designing the IS1595 primers, and Luydson J. N. Souza (Phytobacteriology Laboratory, Universidade Federal Rural de Pernambuco, Pernambuco, Brazil) for technical support.

\section{Literature Cited}

1. Ah-You, N., Gagnevin, L., Chiroleu, F., Juen, E., Rodrigues Neto, J., and Pruvost, O. 2007. Pathological variations within Xanthomonas campestris pv. maniferaeindicae supported its separation into three distinct pathovars that can be distinguished by amplified fragment length polymorphism. Phytopathology 97:1568-1577.

2. Ah-You, N., Gagnevin, L., Grimont, P. A. D., Brisse, S., Nesme, X., Chiroleu, F., Bui Thi Ngoc, L., Juen, E., Lefeuvre, P., Vernière, C., and Pruvost, O. 2009. Polyphasic characterization of xanthomonads pathogenic to members of the Anacardiaceae and their relatedness to species of Xanthomonas. Int. J. Syst. Evol. Microbiol. 59:306-318.

3. Ausubel, F. M., Brent, R., Kingston, R. E., Moore, D. D., Seidman, J. G., Smith, J. A., and Struhl, K. 1992. Current protocols in molecular biology. Vol. 1. Greene Publishing Association, New York.

4. Campbell, C. L., and Madden, L. V. 1990. Introduction to Plant Disease Epidemiology. John Wiley \& Sons, New York.

5. Doidge, E. 1915. A bacterial disease of the mango, Bacillus mangiferae $\mathrm{n}$. sp. Ann. Appl. Biol. 2:1-45.

6. Food and Agriculture Organization of the United Nations. FAOSTAT. Roma. Retrieved 02 February. 2010 from http://faostat.fao.org/site/342/ default.aspx.

7. Gagnevin, L., and Pruvost, O. 2001. Epidemiology and control of mango bacterial black spot. Plant Dis. 85:928-935.

8. Gama, M. A. S., Mariano, R. L. R., Viana, F. M. P., Ferreira, M. A. S. V., and Silveira, E. B. 2009. Sintomas sistêmicos em cajueiro causados por isolados pigmentados de Xanthomonas campestris pv. mangiferaeindicae. Trop. Plant Pathol. 34:14

9. Henz, G. P., Takatsu, A., and Reifschneeider, F. J. B. 1988. Avaliação de métodos de inoculação de Xanthomonas campestris pv. campestris para detecção de fontes de resistência em brássicas. Fitopatol. Bras. 13:207-210.

10. Louws, E. J., Fulbright, D. W., Stephens, C. T., and Bruijn, F. J. 1994. Specific genomic fingerprints of phytopathogenic Xanthomonas and Pseudomonas pathovars and strains generated with repetitive sequences and PCR. Appl. Environ. Microbiol. 60:2286-2295.

11. Manicon, B. Q., and Wallis, F. M. 1984. Further characterization of Xanthomonas campestris pv. mangiferaeindicae. Int. J. Syst. Bacteriol. 34:77-79.
12. Mariano, R. L. R., and Silveira, E. B. 2005. Manual de práticas em fitobacteriologia. 2nd ed. Universidade Federal Rural de Pernambuco, Recife.

13. Nascimento, A. R. P., Mariano, R. L. R., and Gama, M. A. S. 2005. Métodos de preservação e crescimento de Xanthomonas campestris pv. viticola em meio de cultura variando temperatura, $\mathrm{pH}$ e concentração de $\mathrm{NaCl}$. Fitopatol. Bras. 30:650-654

14. Oliveira, V. H. 2002. Cultivo do cajueiro anão precoce. Empresa Brasileira de Pesquisa Agropecuária. Fortaleza. Agroindústria Tropical. Sistemas de Produção No. 1.

15. Papa, M. F. S., Matos, E. C., Almeida, I. M. C., Malavolta Júnior, V. A., and Boliani, A. C. 2001. Ocorrência da mancha-angular (Xanthomonas campestris pv. mangiferaeindicae) em cajueiro no estado do Mato Grosso do Sul. Summa Phytopathol. 27:119.

16. Patel, M. K., Kulkarni, Y. S., and Moniz, L. 1948. Pseudomonas mangiferae-indicae, pathogenic on mango. Indian Phytopathol. 1:147-152.

17. Patel, M. K., Moniz, L., and Kulkarni, Y. S. 1948. A new bacterial disease of Mangifera indica L. Curr. Sci. 6:189-190.

18. Pruvost, O. 1989. La maladie des taches noires de la mangue (Xanthomonas campestris pv. mangiferaeindicae). Etude bactériologique, biologique, épidémiologique et mise au point des bases d'um système de lutte intégrée dans lês conditions de I'île de la Réunion. Ph.D. thesis. Universite' de Paris Sud-Orsay, Paris, France.

19. Pruvost, O. Couteau, A., Perrier, X., and Luisetti, L. 1998. Phenotypic diversity of Xanthomonas sp. mangiferaeindicae. J. Appl. Microbiol. 84:115-124.

20. Quezado-Duval, A. M., Gazzoto Filho, A., Leite Júnior, R. P., and Camargo, L. E. A. 2003. Sensibilidade a cobre, estreptomicina e oxitetraciclina em Xanthomonas spp. associadas à mancha-bacteriana do tomate para processamento industrial. Hortic. Bras. 21:670-675.

21. Rademaker, J. L. W., Louws, F. J., Schultz, M. H., Rossbach, U., Vauterin, L., Swings, J., and De Bruijn, F. J. 2005. A comprehensive species to strain taxonomic framework for Xanthomonas. Phytopathology 95:1098-1111.

22. Robbs, C. F., Neto, J. R., Ribeiro, R. L. D., and Kimura, O. 1981. Annotated list of bacterial plant pathogens in Brazil. Pages 601-612. Proc. 5th Int. Plant Pathogenic Bacteria, CIAT, Cali.

23. Robbs, C. F., Ribeiro, R. D. L., and Kimura, O. 1974. Sobre a posição taxonômica de Pseudomonas mangiferaeindicae Patel et al. 1948, agente causal da "Mancha bacteriana" das folhas da mangueira (Mangifera indica L.). Arq. Univ. Fed. Rur. Rio de Janeiro. 4:11-14.

24. Schaad, N. W., Jones, J. B., and Chun, W. 2001. Laboratory Guide for Identification of Plant Pathogenic Bacteria. 3rd ed. American Phytopathological Society, St. Paul, MN.

25. Schaad, N. W., Postnikova, E., Lacy, G. H., Sechler, A., Agarkova, I., Stromberg, P. E., Stromberg, V. K., and Vidaver, A. K. 2005. Reclassification of Xanthomonas campestris pv. citri (ex Hasse 1915) Dye 1978 forms $\mathrm{A}, \mathrm{B} / \mathrm{C} / \mathrm{D}$, and $\mathrm{E}$ as $X$. smithii subsp. citri (ex Hasse) sp. nov. nom. rev. comb. nov., X. fuscans subsp. aurantifolii (ex Gabriel 1989) sp. nov. nom rev. comb. nov., and $X$. alfalfae subsp. citrumelo (ex Riker and Jones) Gabriel et al., 1989 sp. nov. nom. rev. comb. nov., X. campestris pv. malvacearum (ex Smith 1901) Dye 1978 as X. smithii subsp. smithii nov. comb. nov. nom. nov., X. campestris pv. alfalfae (ex Riker and Jones, 1935) Dye 1978 as X. alfalfae subsp. alfalfae (ex Riker et al., 1935) sp. nov. nom. rev.; and "var. fuscans" of X. campestris pv. phaseoli (ex Smith, 1987) Dye 1978 as $X$. fuscans subsp. fuscans sp. nov. Syst. Appl. Microbiol. 28:494-518.

26. Sneath, P. H. A., and Sokal, R. R. 1973. Numerical Taxonomy: The Principles and Practice of Numerical Classification. University of Leicester, San Francisco.

27. Steyn, P. L., Viljoen, N. M., and Kotzé, J. M. 1974. The causal organism of bacterial black spot of mangoes. Phytopathology 64:1400-1404.

28. Trindade, L. C., Marques, E., Lopes, D. B., and Ferreira, M. A. S. V. 2007. Development of a molecular method for detection and identification of Xanthomonas campestris pv. viticola. Summa Phytopathol. 33:16-23.

29. Viana, F. M. P., Cardoso, J. E., and Saraiva, H. A. O. 2007. First report of a bacterial leaf and fruit spot of cashew nut (Anacardium occidentale) caused by Xanthomonas campestris pv. mangiferaeindicae in Brazil. Plant Dis. 91:1361.

30. Viana, F. M. P., Ferreira, M. A. S. V., Mariano, R. L. R., Saraiva, H. Á. O. and Trindade, L. C. 2006. Mancha-de-Xanthomonas: Nova doença do cajueiro. Empresa Brasileira de Pesquisa Agropecuária. Fortaleza. Boletim de Pesquisa e Desenvolvimento No. 24.

31. Viana, F. M. P., Saraiva, H. A. O., Freire, F. C. O., and Cardoso, J. E. 2005 Ocorrência da bacteriose do cajueiro nos Estados do Piauí e Ceará. Fitopatol. Bras. 30:65.

32. Viana, F. M. P., Saraiva, H. A. O., Freire, F. C. O., and Cardoso, J. E. 2006. Mancha-de-Xanthomonas-do-cajueiro: Sintomas e controle. Empresa Brasileira de Pesquisa Agropecuária, Fortaleza. Comunicado Técnico No. 114 